\title{
Odgovorno roditeljstvo u posinodalnoj apostolskoj pobudnici Amoris Laetitia teološka i pedagogijska perspektiva
}

\author{
Martina s. Ana Begić*, Katarina Dadić**
}

\begin{abstract}
Sažetak
Tema odgovornog roditeljstva nedovoljno je istraživana u hrvatskoj teološkoj literaturi, za razliku od pedagogije gdje joj se pridalo znatno više pažnje. Budući da termin odgovornog roditeljstva te dvije znanosti ne tumače podjednako, autorice su uvidjele potrebu za jasnijom usporedbom teološke i pedagogijske perspektive analizirajući apostolsku posinodalnu pobudnicu pape Franje Amoris laetitia - Radost ljubavi. Teološka perspektiva naglašava da se odgovorno roditeljstvo temelji na ljudskoj odgovornosti koja se nadopunjuje kršćanski oblikovanom savjesti te je kao takvu nudi pedagogiji kao mogućnost. Prva se četiri poglavlja članka odnose na analizu dokumenta Amoris laetitia, a u petom se poglavlju nudi prikaz odgovornog roditeljstva iz perspektive suvremene pedagogijske znanosti.

Ključne riječi: obitelj, dijete, odgovorno roditeljstvo, odgoj, Amoris laetitia
\end{abstract}

\section{Uvod}

Po svojem objelodanjivanju u Crkvi i društvu, posinodalna apostolska pobudnica pape Franje Amoris aetitia (Radost ljubavi) izazvala je različita mišljenja i tumačenja. ${ }^{1}$ Pobudnica obrađuje brojne i različite teme, ${ }^{2}$ što je ujedno i objašnje-

* dr. sc. Martina s. Ana Begić, Katolički bogoslovni fakultet Sveučilišta u Zagrebu. Adresa: Vlaška 38, 10000 Zagreb, Hrvatska. E-pošta: ana.begic@gmail.com

** dr. sc. Katarina Dadić, Filozofski fakultet Sveučilišta u Zagrebu. Adresa: Ivana Lučića 3, 10000 Zagreb, Hrvatska. E-pošta: katdadic@gmail.com

1 Različita tumačenja i rasprave povele su se oko pobudnice Amoris laetita u vezi s njezinim osmim poglavljem, u kojem se posebno raspravlja o pričešćivanju građanski razvedenih i ponovno vjenčanih parova. Po tom pitanju zamjetniji odjek u društvu svakako imalo otvoreno pismo koje su papi Franji uputila četiri kardinala Katoličke crkve: Carlo Caffara, Joachim Meisner, Raymond Leo Burke i Walter Brandmüller. Kardinali navode u predgovoru pisma kako su primijetili među mnogim vjernicima veliku zbunjenost i dezorijentiranost oko nekih iznimno važnih pitanja za život Crkve, a primjećuju i suprotne interpretacije osmog poglavlja pobudnice čak i među članovima biskupskog zbora. Papa Franjo u jednom od svojih intervjua za novine Avvenire dao je kardinalima na neizravan način odgovor i pojašnjenje koje se traži od njega. Pri tome je naveo kako neki misle da su to samo crno-bijela pitanja, čak kad su ona i dijelom vrtloga života, kada smo pozvani razlučivati (Andrijanić, 2016).

2 Pobudnica ima 256 stranica i podijeljena je na devet poglavlja: I. U svjetlu Riječi; II. Stvarnost i izazovi obitelji; III. Pogled upravljen Isusu: poziv obitelji; IV. Ljubav u braku; V. Ljubav koja 
nje njezine opsežnosti. Autorice u svojem radu daju svojevrsnu raščlambu građe samog dokumenta, koncentrirajući se na odnos prema odgovornomu roditeljstvu $^{3}$ i upitnost odgoja iz teološke i pedagogijske perspektive, što označuje da se roditeljska odgojna usmjerenost ne postavlja isključivo kao društveno nametnuto pitanje, nego polazi iz obitelji koja svoje potrebe ukorjenjuje u transcendentnom. To je temeljna sigurnost pape Franje: »Radost Evanđelja ispunja srce i čitav život onoga koji susretne Isusa (EG 5). Samo susret s Kristom može dati radost koja se očituje u izričajima laetitia i gaudium, a ne etička odluka ili prianjanje uz neku ideju. Papin govor odlikuje se prije svega pastoralnom revnošću za navještajem Radosne vijesti u obitelji u svjetlu milosrđa, ${ }^{4}$ nastojeći susresti obitelji u konkretnosti njihovih problema i slabosti, otvarajući za sve ljude putove obraćenja i rasta u ljubavi. Amoris laetitia je zapravo pobudnica o ljubavi u obitelji. Tako ju je

postaje plodna; VI. Neke pastoralne perspektive; VII. Pojačati odgoj djece; VIII. Pratiti, razlučivati i integrirati slabosti; IX. Bračna i obiteljska duhovnost. Iz navedenoga je jasno zašto papa Franjo predlaže čitatelju temeljito i polagano čitanje pobudnice: jer svako poglavlje moguće je primijeniti na različitim područjima društvenih djelatnosti i rada.

3 Postoje razlike u definiciji termina odgovorno roditeljstvo u pedagogiji od teološkog promišljanja ili pristupa. Naime, u pedagogiji se pod tom sintagmom među ostalim kriju i pravni aspekti uređivanja unutarnjih odnosa u obitelji, koji su propisani zakonom i iz kojih nastaju očekivanja, a koja uključuju stvaran doprinos obitelji razvoju osobnosti djeteta, koje se odvija pod utjecajem snažnih i kompleksnih odnosa, uključujući životni stil, skladnost uloga roditelja te prirodu i doživljaj međusobnih veza roditelja i djece (Spasojević, 2011, 123). Određivanje sadržaja odgovornog roditeljstva odvija se u širem društvenom kontekstu, koji obilježavaju brojne promjene u životnim vrijednostima, razumijevanju prirode djeteta i uloge roditelja, društvenom položaju djeteta, majki i očeva (Pećnik, 2008). Stručna literatura iz područja pedagogije govori o poticajnom roditeljstvu (Jeić i dr., 2013), pozitivnom roditeljstvu (Daly, 2008), kompetentnom roditeljstvu (Ljubetić, 2007; Matejević i Todorović, 2012; Ljubetić i Lepičnik-Vodopivec, 2012), dovoljno dobrom roditeljstvu (Ramaekers i Suissa, 2012), autoritativnom roditeljstvu (Zbodulja, 2014), društveno poželjnom roditeljstvu (Petani i Babačić, 2010) te sve navedene termine sjedinjava u koncept odgovornog roditeljstva (Ljubetić, 2011; Ljubetić i Lepičnik-Vodopivec, 2012). Isto tako, stručna radna skupina za definiranje odgovornog roditeljstva, mjera rane pomoći u suočavanju s čimbenicima rizika i izradu prijedloga novih preventivno-savjetodavnih oblika pomoći obitelji u riziku pod okriljem Ministarstva obitelji, branitelja i međugeneracijske solidarnosti 2011. godine odgovornim roditeljstvom smatra društveno poželjno roditeljstvo. Nastavno na navedeno i teolog je pozvan dati odgovor na pitanja polazeći od roditeljstva utemeljenog u odgovornosti, jer sintagma „odgovorno roditeljstvo“ bitno pretpostavlja, štoviše temelji se na ljudskoj odgovornosti. Međutim, Drugi vatikanski koncil ističe kako će supružnici u dužnosti prenošenja i odgajanja ljudskog života ispuniti svoju zadaću s ljudskom i kršćanskom odgovornosti i s poučljivim poštovanjem prema Bogu. Kršćanska odgovornost u konkretnom životu predstavlja dosljedno i požrtvovno ostvarivanje ljudske odgovornosti koja proizlazi iz ispravno oblikovane savjesti (Matulić, 2001).

4 Govor o milosrđu posebno je obilježje pontifikata pape Franje. Na svetkovinu Bezgrešnog začeća 8. prosinca 2015. godine otvorio je vrata vatikanske bazilike sv. Petra, čime je započela sveta Godina Božjeg milosrđa, koja je trajala do svetkovine Krista Kralja 2016. godine. Izvanrednu godinu milosrđa Papa je proglasio bulom Misericirdiae vultus. »'Strpljiv i milosrdan', ta dva izraza koja se pojavljuju u Starome zavjetu često se javljaju zajedno pri opisivanju Božje naravi. Njegova se milosrdnost konkretno pokazuje u mnogim djelima povijesti spasenja, gdje njegova dobrota prevladava pred kaznom i uništenjem. Božje milosrđe nije neka apstraktna ideja, već konkretna stvarnost kojom on objavljuje svoju ljubav kao ljubav oca i majke koji osjećaju duboku privrženost prema svome djetetu. Ljubav izvire iz dubine bića kao dubok, prirodan osjećaj, satkan od nježnosti i suosjećanja, oprosta i opraštanja« (MV 6). 
okarakterizirao i kardinal Christoph Schönborn kada je govorio o ključnim pojmovima dokumenta. U prvom redu istaknuo je ljubav, a sam dokument nazvao je hvalospjevom obiteljskoj ljubavi koji progovara o punini osjećaja unutar obitelji, ponašanju bračnog para, o obiteljskom bogatstvu i sl. Četvrto poglavlje pobudnice proglasio je svojevrsnom jezgrom teksta (Schönborn, 2016). Kršćanska ljubav je ljubav ako proizlazi i svoju snagu crpi iz vjere u Isusa Krista, koja preobražava cijelog čovjeka, pa tako i njegovu ljubav. »Kršćanin nikad ne ljubi zato što ljubi, kršćanin uvijek ljubi in Christo, u Kristu« (Raguž, 2017)..$^{5}$ Bit ljubavi u obitelji tako proizlazi iz Krista. Intenzivna usmjerenost pobudnice na ljubav u obitelji autorice posebno navodi na temu odgovornog roditeljstva, koja se proteže kao nit vodilja pojedinim poglavljima pobudnice.

\section{Stvarnost, izazovi i poziv današnjih obitelji u kontekstu pobudnice Amoris laetitia}

Tijekom povijesti čovječanstva svako je vrijeme sa sobom nosilo određene krize, relativizacije i poljuljanosti vrednota. Čovjek je u svijetu i svijet je za čovjeka u bolnoj stvarnosti postojanja. Kao razumno biće čovjek ima mogućnost spoznaje i vrednovanja. S obzirom na to da je mobilnost slobodnog ili poslovnog života obilježena tehničkim dostignućima, gase se kućna ognjišta, remete se ljudski odnosi, počevši od obitelji gdje više nema zajedništva u klasičnom smislu riječi, pa sve do odnosa s drugima (Koprek, 1997). Vrijeme u kojem živimo obilježeno je različitim krizama koje svoje temelje pronalaze u procesima globalizacije, sekularizacije, hedonizma, liberalizma, ${ }^{6}$ a koji zahvaćaju temeljne vrednote našeg življenja. ${ }^{7}$

5 »Čin ljubavi za kršćane dolazi iz čina vjere, ljubav proizlazi iz odluke vjere u Isusa Krista: u vjeri znamo da nas Krist ljubi i zato ljubimo. Mi ne ljubimo jer smo sobom raspoloženi za ljubav, nego ljubimo jer smo odlučili ljubiti. Bez Krista teško ljubimo, bez Krista ne ljubimo istinski. Jer, kad susretnemo druge ljude, ograničene, zle, ružne, drukčije vjere i rase, drukčijih svjetonazora, sve se u nama protivi ljubavi. Ako ih ne mrzimo, onda ih uopće ne doživljavamo, ili se pak pozivamo na toleranciju, što je često samo druga riječ za ravnodušnost. Ali, kad se sjetimo koliko nas je Bog u Isusu Kristu ljubio, kad pogledamo na Kristov križ, na Krista koji je predao svoj život za nas, bijednike i grešnike, kad priznajemo da je Bog, stvoritelj i temelj ove zbilje, sama ljubav, tada ne možemo ne ljubiti« (Raguž, 2017).

6 Kršćanska vjera svoj oslonac ima u Kristu i u tom kontekstu promatrana svoje temelje ne pronalazi u povlasticama, pozicijama i moći kojih je oduvijek bilo. Iz njenog utemeljenja u Kristu svaki autentični poziv na cjeloviti ljudski razvoj ima svoj oslonac. Ljubav treba biti središte svakog poziva. Suvremenom globaliziranom svijetu potreban je proces humanizacije globalizacije koji bi u svom središtu imao stvarnog čovjeka (Tomašević i Begić, 2010). U takvome svijetu prvo mjesto trebala bi zauzimati kultura darivanja umjesto kulture svemoći i tržišta (Tomašević i Begić, 2010). No nažalost, danas se upravo događa suprotno, a time se oduzima primat etici i u kontekstu takvog usmjerenja života rađaju se različiti procesi koji čovjeka odvlače od njegova središta, od Krista.

7 Problem kontinuiteta, odnosno diskontinuiteta odgojnih vrijednosti detaljno razrađuje i Pranjić. On nijansira ideju o vrijednostima ističući dva smjera njihove promjene: prvi uključuje socijalni aspekt u smislu očuvanja tradiranih vrijednosti koji se često odvija i na štetu daljnjeg rasta i razvoja, kako društva tako i same osobe, a drugi je znatnije usmjeren prema individualnomu, tj. 
Kako govoriti o odgovornom roditeljstvu ${ }^{8}$ ako se ne osvrnemo na temelj iz kojeg sve proizlazi, a to je obitelj. Obitelj je prva ljudska zajednica, određena temeljnom biološkom, psihološkom, čuvstvenom i kulturalnom istorodnošću. Prvotna je i temeljna stanica društva (Capelli, 2009, 747), no isto tako valja naglasiti da je gospodarski, socijalni i moralni kontekst suvremenog zapadnog društva proizveo velike promjene unutar obitelji. Stanje antropološko-kulturnih promjena odnosi se na sve vidike života i zahtijeva temeljiti analitički i raznoliki pristup (AL 32). Obitelj je uvijek bila obitelj kao ona koja se sastoji od supružnika i djece, i ona će to i ostati, samo što neki ne uočavaju njezin izvorni smisao, koji nipošto nije uperen protiv njih, nego im upravo suprotno dolazi ususret sa svim svojim pozitivnim nabojima. Nažalost te pozitivne naboje oni ne vide jasno i zbog toga nastupa kriza obitelji, najprije u smislu poremećaja u obiteljskim odnosima, potom kao rasulo obiteljskih zadaća i odgovornosti, a na kraju kao drastičan pad interesa za zasnivanje obitelji. Istinska kriza obitelji proizlazi iz izmijenjene ljudske svijesti i savjesti koje prosuđuju i odlučuju o dostojanstvu i vrijednosti obitelji (Matulić, 2009). Temeljni je problem u svjesnosti da je osnovni smjer u kojem se kreću antropološko-kulturne promjene takav zbog kojeg se pojedinci u osjećajnom i obiteljskom životu više ne mogu kao nekoć osloniti na društvene poveznice. S druge pak strane treba uzeti u obzir pretjerani individualizam koji izobličuje obiteljske veze i u konačnici svakog člana obitelji promatra kao jedan otok, što ima za posljedicu da u određenim slučajevima prevladava poimanje pojedinca kao osobe koja izgrađuje samu sebe prema vlastitim željama koje se shvaćaju kao apsolutnost (AL 32 i 33). Naglašena individualistička kultura posjedovanja i užitka dovodi do promjena odnosa u obitelji. U današnjem svijetu individualizam $^{9}$ i usmjerenost na sebe doživljava procvat u punom smislu te dovodi

individualističkim vrijednostima, uz rizik da se na pijedestal stavi hedonističko umjesto općeprihvaćenoga (Pranjić, 2010).

8 Izgleda nam paradoksalno da sam izraz susrećemo po prvi put u enciklici Pavla VI. Humanae vitae: »Bračna ljubav traži od bračnih drugova svijest u njihovu poslanju 'odgovornog roditeljstva', koje se danas s punim pravom toliko naglašava i koje također treba ispravno shvatiti. Ono se treba promatrati s raznih opravdanih i međusobno povezanih gledišta (HV 10). Papa se dotiče biološkog, psihološkog, ekonomskog, društvenog i moralnog gledišta. Odgovorno roditeljstvo u odnosu prema biološkim procesima označava vrednovanje i poštivanje različitih tokova: »um u sposobnosti prenošenja života otkriva biološke zakone koji su sastavni dio ljudske osobe « (HV 10). Odgovorno roditeljstvo ili odgovorno očinstvo i majčinstvo moguće je u užem smislu izraziti kao dužnost supružnika da rađaju po načelu velikodušnosti i razboritosti. Rađanje je bitan zahtjev bračnog staleža, ali i način primjene uvijek je podložan sudu razboritosti i hrabrosti bračnih drugova prema moralnim normama koje ga upravljaju. Drugi vatikanski koncil u dokumentu $G a-$ udium et Spes jasno ističe kako supružnici znaju da su u dužnosti prenošenja i odgajanja ljudskog života suradnici ljubavi Boga Stvoritelja. Međusobnim razumijevanjem oni će stvoriti ispravan sud imajući pred očima osobno dobro i dobro već rođene djece ili djece koju predviđaju da će se roditi (GS 50). Isto tako, odgovorno roditeljstvo od supružnika zahtijeva svjesnost da postoje situacije i uvjeti u kojima bi bilo neodgovorno rađati djecu. Koncil otvoreno izjavljuje da roditelji trebaju biti dalekovidni u preuzimanju svojih odgovornosti koje dolaze rođenjem novog djeteta. Odgovorno roditeljstvo nema ništa zajedničkog sa samovoljnim neodgovornim ponašanjem u braku (Fuček, 1974; Fuček, 1979).

9 Beck podrazumijeva individualizaciju kao povijesni proces koji dovodi u pitanje tradicionalnu konstrukciju pojedine osobe. Beck to naziva „normalnom biografijom“, a njegova teza je da su 
do obiteljskog otuđenja. Promjene su to koje su teorijski afirmirane u konceptima postsocijalnih odnosa u kojima interakcije s objektima postaju učestalije i bitnije od interakcija s drugima, koji nastaju kada pojedinac povezuje svoje želje s objektom, kada se pojedinac potvrđuje i proširuje objektom, a subjekt postaje definiran objektom (Knorr Cetina i Bruegger, 2002, 178). Iz toga slijedi da osoba postaje objekt opisa, klasifikacije i tumačenja. Stojimo nasuprot sebi samima kao netko drugi i nešto drugo. Neće li to podvajanje čovjeka završiti otuđenjem? Nećemo li zaboraviti njegovo polazište, tj. da to drugo nije ono prvo, nego nešto drugo, produkt jednog odpredmećivanja, i da tim putem stečeno znanje nije naš neposredno proživljeni bitak, nego samo, ali ipak njegova slika? U slici mora biti moguće spoznati samu odslikanu stvar (Haeffner, 2003: 20), koja zapravo predstavlja polazišnu osnovu za pedagoški način gledanja na dijete u smislu da je ono i antropološka slika. Antropološko pitanje tko je čovjek, odnosno što je čovjek, širi našu perspektivu s partikularnog na univerzalno ljudsko.

Osim pojave individualizma u pobudnici se spominje i sloboda izbora koja svakomu omogućuje planirati svoj život i odnjegovati ono najbolje u sebi. No, ako ta sloboda nema plemenite ciljeve i osobnu disciplinu, lako se izrodi u nesposobnost velikodušnog sebedarja. Kada spomenute činjenice utječu na način na koji se shvaća obitelj, može se dogoditi da se ona pretvori u prolazno mjesto, gdje se pojedinac ponaša onako kako mu odgovara tako da se utječe obitelji kada to smatra potrebnim ili gdje ide tražiti prava (AL 32, 33 i 34).

Antropologija koju je Crkva tradicionalno koristila i/ili jezik kojim ju je izražavala ostaju čvrst temelj i plod mudrosti stoljetnog iskustva. Ipak, postmoderni suvremeni čovjek kojemu se Crkva danas obraća ne uspijeva razumjeti poruku Crkve ili je pak ne smatra dovoljnom te ne primjećuje snagu njezine radosti. Papa je uvjeren da kršćanska vizija braka i obitelji i danas ima nepromjenjivu snagu privlačnosti, ali zahtijeva i »zdravu samokritičnost«. Pozvani smo stoga odgajati savjesti, a ne težiti tomu da ih zamijenimo. Moramo biti zahvalni na tome što većina ljudi ipak cijeni obiteljske odnose koji su trajni i označeni uzajamnim poštovanjem (AL 37 i 38). Obitelji se često osjećaju napuštenima zbog nezainteresiranosti ili slabe pažnje od strane institucija. Obitelj treba biti zaštićena jer je ona dobro bez kojeg društvo ne može (AL 43 i 44).

Obitelj u suvremenom društvu ne nosi više breme samoodržavanja društva, osim u dijelu demografskog rasta i željene socijalizacije, što je opet neraskidivo povezano s drugim društvenim čimbenicima koji osiguravaju društveni napredak, uključujući i odgovarajuće socijalno-ekonomske, uslužne, obrazovne te druge uvjete za odgovorno rađanje i predano odgajanje djece. Suvremena obitelj može se posvetiti bitnome, a to je odgoj, skrb, briga za pomladak, jačanje intimnih obiteljskih veza te razvijanje svijesti o obiteljskoj solidarnosti (Matulić, 2009, 292-293).

ljudi sve više prisiljeni stvarati, odnosno inscenirati vlastitu biografiju bez vrijednosti i pravila. Istovremeno su uvučeni u mrežu institucionalne kontrole, koja je dio moderne (socijalna država, tržište rada, obrazovni sustav itd.). Tako „normalna biografija“ postaje zapravo „,amaterska biografija“. On zaključuje kako je u ranijim društvenim epohama tradicija pružala pojedincima jasno definirane uloge te je kao takva bila temelj društvenog uređenja. S postindustrijskom modernizacijom jačala je individualizacija i pluralizacija identiteta (Beck, 1987). 
Stoga je »nužno da budemo realisti i ne uzimamo zdravo za gotovo, da naši sugovornici poznaju čitavu pozadinu onoga o čemu govorimo ili da mogu povezati ono što govorimo s bitnom srži Evanđelja, koja tomu daje smisao, ljepotu i privlačnost « (EG 34).

\section{Odgovorno roditeljstvo}

»Obitelj je, kao 'izvor i temelj ljudskoga društva' (AA11), pozvana biti školom društvenosti, mjestom i oruđem humanizacije i odgoja za odgovornost $u$ društvu (usp. FC 43)«(Capelli, 2009, 749). Po svojem unutarnjem i najdubljem smislu svojega postojanja ona je prava škola potpune čovječnosti. Djeca u obitelji stječu prvo iskustvo o zdravoj ljudskoj zajednici i o Crkvi, po njoj ulaze posebno u ljudsku zajednicu i u Božji narod (Matulić, 2009). Danas se obitelji susreću s različitim, a ponekad i neizbježnim problemima u odgoju djece. U pobudnici se tako ističe stanje kako u većini slučajeva mnogi roditelji nakon posla dolaze kući iscrpljeni i bez volje za razgovorom, u mnogim je obiteljima zamro običaj zajedničkog objedovanja. Nudi se mnoštvo zabava, uključujući, između ostaloga, i ovisnost o televiziji i računalu. Obitelji danas često boluju od goleme tjeskobe i stresa. Jedan je od izazova današnjice i velika odsutnost očeva, koja ostavlja teške tragove u obiteljskom životu. Oni mogu biti tjelesni, osjećajni, umni i duhovni. Djeci nedostaje prikladan uzor očinskog ponašanja. Pojavom kriza autoriteta automatski dolazi do krize očinstva, ali snaga obitelji izvire iz moći da ljubi i druge pouči kako ljubiti, jer koliko god obitelj bila ranjena, uvijek umije sazrijevati polazeći od ljubavi (AL 50.53 i 55).

Papa nas stoga poziva da cjelokupni nauk (doktrinu) braka i obitelji postavimo pod svjetlo kerygme. Potrebno je da pred obiteljima i u obiteljima uvijek iznova odzvanja prvotni navještaj onoga što je »najljepše, najprivlačnije i istovremeno najnužnije«. Razlog tomu je cjelokupna kršćanska formacija koja je prije svega produbljenje kerygme (AL 58). Pobudnica Amoris laetitia o odgovornom roditeljstvu govori u kontekstu priziva na encikliku Humanae vitae blaženog pape Pavla VI., koji je na tragu Drugog vatikanskog koncila produbio nauk o braku i obitelji. Riječ je o rasvjetljivanju naravne veze između bračne ljubavi i začeća:

bračna ljubav traži od bračnih drugova svijest o njihovu poslanju odgovornog roditeljstva koje se danas s punim pravom toliko naglašava i koje također treba ispravno shvatiti. Ostvarivanje odgovornog roditeljstva uključuje, dakle, i to da bračni drugovi u potpunosti priznaju vlastite dužnosti prema Bogu, prema samima sebi, prema obitelji i ljudskom društvu, u ispravnom redoslijedu vrednota (AL 68).

Dijete koje se rađa ne dolazi izvana da se pridoda uzajamnoj ljubavi supruga: niče iz samog srca njihova uzajamnog dara, kojemu je plod i dovršenje. Ne dolazi kao ishod nekog procesa, već je prisutno od početka njihove ljubavi kao bitna karakteristika koja se ne može zanijekati, a da se pritom ne izobliči sama ljubav između onih koji se vole. Od samoga početka ljubav odbacuje svaki poticaj na zatvaranje u sebe i otvara se plodnosti koja je proteže dalje od vlastite egzistencije (AL 80). 
Dijete zaslužuje da bude rođeno iz takve ljubavi, a ne bilo kojim drugim sredstvom, jer dijete nije neki dug, nego dar, koji je plod točno određenog čina bračne ljubavi svojih roditelja (AL 81).

Odgoj djece jedan je od temeljnih izazova s kojima se suočavaju današnje obitelji, a suvremena kultura i veliki utjecaj medija čine ga zahtjevnijim i kompleksnijim. Papa Franjo naglašava važnost cjelovitog odgoja djece kao osobitog prava i dužnosti roditelja. Odgoj nije samo zadaća ili teret, nego bitno i neotuđivo pravo koje su roditelji pozvani braniti i nitko nema pravo tražiti da im se to uskrati. U obrazovanju djece država ima supsidijarnu ulogu, i to tako da prati i podupire roditelje u njihovoj ulozi. Roditelji su slobodni birati samostalno vrstu obrazovanja koju žele dati svojoj djeci u skladu sa svojim uvjerenjima. Škola ne zamjenjuje roditelje, nego ih nadopunjuje. Načelo je sljedeće: svaki drugi sudionik u odgojnom procesu ne može nego djelovati u ime roditelja, s njihovom suglasnošću i u određenoj mjeri. Međutim, danas je došlo do raskola između obitelji i društva, ističe papa Franjo, i tako je došlo do krize jer je potkopano uzajamno povjerenje između obitelji i društva (AL 84).

Molim, hvala i oprosti tri su važne riječi koje se u kontekstu govora o ljubavi koja se očituje i raste u obitelji ističu u pobudnici. To su ključne riječi za odgoj djeteta. »Kada u obitelji nema previše nametljivosti i kada se nauči reći 'molim', kada u obitelji nema egoistâ i kada se u njoj nauči reći 'hvala', i kada u obitelji neki njezin član primijeti da je učinio nešto loše i zna reći 'oprosti', tada u toj obitelji vladaju mir i radost «(AL 133). Kako bi obitelj sazrijevala i rasla, drugi bitan element je dijalog, koji je povlašteno i prijeko potrebno sredstvo za življenje, izražavanje i sazrijevanje u ljubavi i u bračnom i u obiteljskom životu. Komunikacija može biti uvjetovana načinom na koji postavljamo pitanja i odgovaramo na njih, ton kojim se služimo kao i sam trenutak. Prijeko je potrebno razviti stajališta koja izražavaju ljubav i omogućuju istinski dijalog. Izdvojiti vrijeme, kvalitetno vrijeme, biti spreman strpljivo i pozorno slušati drugoga što želi reći zahtjev je samodiscipline da ne počnemo govoriti prije nego dođe pravi trenutak (AL 136 i 137).

Iako se $u$ pobudnici svi navedeni čimbenici referiraju na bračnu ljubav i one koji u njoj žive, kada dođu djeca bez odgoja i svraćanja pozornosti na navedene činjenice, bit će oslabljen i okrnjen odgoj djece.

Mentalitet koji samo može reći: 'to je nekad bilo, sad su neka druga vremena', u konačnici je nezreo. Poznavati i zauzeti stajalište prema događajima iz prošlosti jedini je način da se izgradi smislena budućnost. Odgoj nije moguć bez sjećanja [...] slušati starije dok pripovijedaju dobro je za djecu i mlade, to im daje osjećaj povezanosti s poviješću obitelji (AL 193).

\section{Intenzivirati odgoj djece}

Prodor štetnih utjecaja koji su u izravnoj vezi s odgojem djeteta izbjeći će se samo ako se s djecom bude razgovaralo te im se jednostavno i s ljubavlju bude 
posvetilo vrijeme. ${ }^{10}$ Ipak, ni pretjerana briga ${ }^{11}$ nije dobra za odgoj i ne smije se imati kontrolu nad svim situacijama u kojima se dijete može naći i kroz koje može prolaziti. »Odgajati ne znači biti opsesivan i preuzeti kontrolu nad svim, nego 'promicati odgovornu slobodu' koja će znati dobro izabrati. Moralni odgoj djece roditelji nikada ne mogu delegirati« (An., 2016). Ako se osvrnemo na naše društvo u kojem trenutačno živimo i jesmo, tada uviđamo činjenicu kako u »nedostatku valjanih metoda odgoja svagdašnjicu obitelji karakterizira udovoljavanje ekstremnim zahtjevima razmaženoga djeteta ili roditelji, u strahu i nesigurnosti zbog mogućih pogrešaka u odgojnom usmjeravanju, prepuštaju dijete nekoj vrsti samoodgoja « (Štengl, 2015). ${ }^{12}$

Djelotvoran etički odgoj osobe ukazuje samo na one čine koji su ispravni zbog toga što je danas često neučinkovito tražiti ono što zahtijeva napor i odricanje ako se jasno ne pokaže dobro koje se time želi postići. U odgoju je važno jačanjem volje razvijati dobre navike, te ponavljanjem određenih radnji izgrađivati moralno vladanje (AL 265-266).

Moralni je odgoj povezan s njegovanjem slobode pomoću prijedloga, poticaja, praktičnih primjena, razmišljanja, ohrabrenja, stalnog preispitivanja našeg načina djelovanja i dijaloga, koji pomaže osobama razviti ona čvrsta unutarnja načela koja ih vode do toga da spontano čine dobro (AL 267).

Pobudnica raspravlja o vrijednosti opomene kao poticaja u odgoju djeteta, kako bi dijete osjetilo strpljivost i povjerenje svojih roditelja. Dijete koje se ispravlja ljubavlju osjeća se cijenjeno. Važno je senzibilizirati dijete i mladog čovjeka da shvate kako nedolično ponašanje za sobom povlači posljedice te kako stega ne dovodi do obeshrabrenja, nego ju treba shvatiti kao poticaj za daljnji napredak (AL 268-270). Sposobnost čekanja je također neophodna u odgoju djece. Danas kada dominiraju stres, užurbanost i streloviti tehnološki napredak, ta sposobnost jedan je od najvažnijih zadataka. Odgađanje želje ne znači i njezi-

10 Dok je zajedništvo nekada značilo raditi stvari zajedno, danas (zbog promijenjenih obiteljskih obrazaca) ono znači biti u istom odnosu, ali da pri tom svatko radi „svoj posao“ što se poglavito očituje u potrošačkom okruženju.

11 Cline i Fay pretjeranu roditeljsku brigu dočaravaju metaforom helikopter roditelj s ciljem opisivanja roditelja koji bdiju nad svojom djecom rješavajući sve njihove probleme (Cline i Fay, 1990). Takve pedocentrične koncepcije izražavaju se primjerice u pedagoškoj literaturi i kroz over-parenting (Bernstein i Triger, 2011), total parenting (Smith, 2010), paranoid parenting (Furedi, 2008).

12 Procesu redefiniranja uloge oca i majke danas sve više doprinosi činjenica da brigu oko djece $\mathrm{i}$ dalje većinom snosi žena i majka. »Odluka za roditeljstvo za nju trenutno znači odustajanje od karijere, ali dobro osmišljena socijalna politika i društvena podrška može ipak pomoći relativno brzom povratku žene u svijet rada te na taj način može pospješiti odluku na majčinstvo, odnosno ulazak u brak « (Štengl, 2015, 706). Uloga oca u novim sociokulturnim uvjetima postaje još nejasnije definirana. Ono što je donedavna bila njegova specifična zadaća u obitelji, kao na primjer naimcanje materijalnih resursa a što je ujedno i njegov muški identitet podupiralo, danas mora biti spojivo sa zahtijevima aktivnog uključivanja u roditeljstvo, a što sa sobom obevzuje uključivanje u roditeljstvo, odgajanje i kućanske poslove. U takvim promijenjenim okolnostima, uz nejasno poimanje roditeljstva, pojedincu je teško udovoljiti postavljenim standardima odgovornog roditeljstva, kako ga podrazumijevamo u kontekstu promatranja sa teološkog gledišta, a što sve više danas rezultira odgađanjem odluke mnogih osoba za ulazak u brak i zasnivanje obitelj (Štengl, 2015). 
no nijekanje, potrebno je jednostavno odgađati njezino ispunjenje, kako bi djeca usvojila sposobnost čekanja, naučila se samokontroli i neovisnosti o vlastitim nagonima. Kada dijete shvati da mora biti odgovorno prema samomu sebi, time obogaćuje i vlastito samopoštovanje (AL 275-276). Samopoštovanje se obogaćuje i pitanjem spolnog odgoja, kojemu nije lako pristupiti u vremenu u kojem se spolnost teži banalizirati i osiromašiti.

Spolni odgoj bi se trebalo promatrati u širem okviru odgoja za ljubav i uzajamno darivanje. Na taj način jezik spolnosti ne bi bio tužno osiromašen, već prosvijetljen i obogaćen. Spolni nagon može se pravilno usmjeravati kroz proces rasta u samospoznaji i samokontroli, koji može odnjegovati dragocjene sposobnosti radosti i susreta u ljubavi (AL 280).

Spolni bi odgoj trebao pružiti informacije pri čemu bi trebalo imati u vidu da djeca i mladi još uvijek nisu stekli punu zrelost. Nema koristi od zasipanja informacijama koje im neće pomoći da razviju kritički smisao (AL 281). »Spolnost je temeljna dimenzija osobnosti, jedan njezin način postojanja, očitovanja, ophođenja s drugima, osjećanja, izražavanja i življenja ljudske ljubavi« (Ivan Pavao II., 2003, 14). »Spolnost koju ljubav usmjerava, uzdiže, kao takva poprima značaj prave ljudske vrednote« (Odgojne smjernice o ljudskoj ljubavi, 6).

Spolni odgoj koji pomaže osobi sačuvati zdrav osjećaj stida ${ }^{13}$ ima golemu vrijednost, ma koliko neki mislili da to pripada nekim drugim vremenima. Stid je prirodno sredstvo kojim osoba brani svoju nutrinu i štiti se od toga da bude pretvorena u puki objekt. Ako nema stida može se dogoditi da se ljubav i spolnost svedu na opsjednutosti genitalnošću i bolesnim stanjima koji izobličuju našu sposobnost za ljubav, kao i oblicima seksualnog nasilja koji vode do nehumanog postupanja ili do toga da se povrijedi drugoga (AL 282).

U spolnom odgoju djece i mladih važno je isticati osjetljivost za različite izraze ljubavi, uzajamne brige, nježnosti i poštivanje te duboko smislene komunikacije. Sve to priprema osobu za cjelovito i velikodušno sebedarje, koje će se izraziti, nakon javnog prihvaćanja obveze, u daru tijelâ. Potrebno je cijeniti vlastito tijelo, u svojoj ženskosti i muškosti, kako bi se mogli prepoznati u susretu s nekim tko je drugačiji. Spolni odgoj stoga mora pomoći osobi da prihvati vlastito tijelo tako da ona ne teži za brisanjem spolne razlike jer se ne zna s njom suočiti (AL 283286). Spolnim bi se odgojem trebala postići afektivna zrelost osobe, jer ljubav i zauzetost odgajaju za vrednotu, za dostojanstvo i poštivanje života, tijela, spola i zdravlja (Odgojne smjernice o ljudskoj ljubavi, 72, 105), a to je također jedan od zadataka odgovornog roditeljstva.

13 Stidljivost s moralnog gledišta je kao neka budna svijest što brani čovjekovo dostojanstvo i istinsku ljubav. Ona se odupire određenomu ponašanju i koči postupke koji potamnjuju dostojanstvo osobe. Neophodno je i djelotvorno sredstvo za gospodarenje nagonima (Odgojne smjernice o ljudskoj ljubavi 90). 


\section{Pedagogijska perspektiva odgovornog roditeljstva}

Moderna pedagogijska znanost o pristupu odgovornomu roditeljstvu i odgoju pristupa sasvim drugačije od načina koji je papa Franjo istaknuo u svojoj pobudnici. Naime, pedagogija aktivno dvoumi je li "roditeljska odgojna filozofija" obiteljsko ili društveno pitanje i sklona je i mijenjanju postojećih paradigmi (Ljubetić, 2011) u smislu da položaj djeteta u suvremenom svijetu izravno utječe na roditeljsku ulogu tako da obiteljski odgoj čini pomak od privatne u javnu sferu te postaje predmetom javnih politika (Maleš, 2012). Istina je da pedagogija ne bježi od holističkog i interdisciplinarnog pristupa u pripremi roditelja za odgovorno roditeljstvo, ali ne stavlja ni duhovnu (religijsku) perspektivu u prvi plan jer joj često pripisuje neznanstvenost tražeći često rješenje u samim akterima odgoja. Naime, smatra se da se takav pristup ne temelji na znanstveno utvrđenim paradigmama koje su važeće u određenom društvenom i civilizacijskom kontekstu. Mnoge od njih (paradigme), koje su odolijevale promjenama stotinama godina i koje su bile temelj za odgoj desetaka generacija djece, posljednjih desetljeća intenzivno se propituju, stavljaju u fokus znanstvenih istraživanja i (ne)opravdano dovode u pitanje (Ljubetić, 2011).

Primjetno je da se u procesu intenzivne sekularizacije napravio odmak međusobnih utjecaja teologije i pedagogije, za razliku od onoga kako je to bilo u prvoj polovici 20. stoljeća na području Europe, primjerice u djelima Diltheya, Litta i Sprangera, u kojima su glavni problemi odnos duhovnih znanosti s pedagogijom i kulturom bili ključni. Odgoj kao proces njihova međusobnog djelovanja bio je glavna meta tadašnje europske pedagoške misli nastaloj na tradiciji duhovno-znanstvene filozofije. Uvažavanje duhovnoga bilo je intenzivno prisutno i u pedagoškoj antropologiji Marije Montessori, koja je bila otvorena prema svemu što je otkrivalo cjelovitu sliku osobe u konstitutivnom jedinstvu tijela, duše i duha $\mathrm{s}$ jedne strane, a u isto je vrijeme bila kritična prema svim zatvorenim znanstvenim sustavima koji su jednodimenzionalno reducirali ljudsku osobu na štetu drugih dimenzija. U tom smislu ona daje važno mjesto upravo duhovnoj dimenziji djeteta. Međutim, moderna stremljenja u načinu života iznjedrila su neke nove vrijednosti, među kojima se na pijedestalu pojavio liberalizam, koji je izravno utjecao na jačanje filozofije inidividualizma i višestrukih mogućnosti slobode izbora načina života. Sve je to utjecalo na promjenu uloga muškaraca, žena i djece, što je rezultiralo i promjenama u partnerskim i obiteljskim oblicima života (Wilk, 2003; Ljubetić, 2011; Maleš, 2012). Navedene promjene u postmodernim obiteljima odrazile su se izravno na odgojne mogućnosti obitelji, kao i na samu prirodu obiteljskog odgoja. No zanimljivo je ipak istaknuti kako Juul i Jensen (2012) upozoravaju da suvremena društva (unatoč svjesnosti o problemu) ipak nisu odgovorila zahtjevima odgovornog roditeljstva, što se najčešće očituje pojavom epidemije popustljivog odgoja (Elkind, 1995; Sunko, 2008). S druge strane imamo potrebu spašavanja djece od hiperroditeljstva (Honoré, 2009), koje je također produkt suvremenosti. Elkind stoga sintagmom stara neravnoteža zadovoljavanja potreba djece i njihovih roditelja pokušava predočiti da se sve kreće u suprotnom smjeru, tj. u smjeru popustljivih i postmodernih obitelji i odnosa (Elkind, 1995). 
U mnoštvu informacija o odgoju djece s kojima se roditelji susreću, potrebno ih je usmjeriti prema onima koje će im koristiti u stvaranju poželjnog roditeljstva. Savjeti, upute, procedure, pritisak potrošačkog društva čine roditeljstvo iznimno složenom životnom zadaćom (Lozančić i Kunert, 2015), a naglasak na duhovnom gotovo je i zaboravljen, iako se u pedagogiji i dalje smatra da je roditeljsko odgojno djelovanje pod snažnim utjecajem religijskih, filozofskih, kulturnih i inih tekovina (Ljubetić, 2011). Ipak, Amoris laetitia može se smatrati jednim od novih iskoraka i u područje pedagogije obraćajući se kršćanskim roditeljima kako bi putem zadaće odgoja obogatili perspektivu svojeg odgovornog roditeljstva.

\section{Zaključak}

Papa Franjo želi otvoriti novi put navještaja Radosne vijesti o braku i obitelji za život cijele Crkve. Temeljno pitanje u kontekstu tog promišljanja nije bilo kazuističke naravi, nego hitnosti navještaja „onoga što Krist donosi obiteljima“. Istraživanjem područja koje se dotiče teme odgovornog roditeljstva proučili smo nekolicinu znanstvenih radova koji se u teologiji okvirno dotiču spomenute materije. »Ako je potomstvo temeljni uvjet održavanja života, roditeljstvo je preduvjet tog uvjeta. Nema i ne može biti potomstva bez roditeljstva ni roditeljstva bez potomstva. To su dvije strane iste pojave, dvije bitne sastavnice u procesu rađanja [...] Zašto se kod odgovornog roditeljstva naglašava odgovornost? Želi li se napomenuti da uz odgovorno postoji i neodgovorno? U životu, nažalost imamo i takva roditeljstva. Odgovornost i neodgovornost moralne su, etičke i vrijednosne kategorije. Moral je samo ljudski fenomen i izrazito ljudsko obilježje. Pojam roditeljstva ima dva značenja; biološko i etičko. Ljudski odnos prema potomstvu je svjestan, namjeran, plod je slobodne ljudske odluke, ima sva obilježja moralnoga čina i stoga se na njega primjenjuju etički, vrijednosni kriteriji« (Vukasović, 2009). Iz rada je jasno da je tema odgovornog roditeljstva nedovoljno istraživana u hrvatskoj teološkoj literaturi, za razliku od pedagogije, gdje joj se pridalo znatno više pažnje. Sam termin te dvije znanosti ne tumače potpuno jednako, zbog čega su autorice uvidjele potrebu za jasnijim isticanjem teološke i pedagogijske perspektive u odnosu na odgovorno roditeljstvo analizirajući apostolsku posinodalnu pobudnicu pape Franje Amoris laetitia. Teološka perspektiva otkriva pastoralnu dimenziju važnosti govora o odgovornom roditeljstvu i odgoju djeteta, a pedagogijska perspektiva raščlanjuje promjene u postmodernom svijetu, koje su se izravno odrazile na odgojne mogućnosti obitelji, kao i na samu prirodu obiteljskog odgoja i rješenje vidi u samim akterima odgoja. U mnoštvu informacija o odgoju djece s kojima se obitelji susreću, u pedagogiji je naglašen imperativ stvaranja poželjnog roditeljstva, koje se nužno ne mora realizirati putem duhovne dimenzije, koja je okosnica analizirane pobudnice, ali i teološkog pristupa. Teološka perspektiva tako naglašava da se odgovorno roditeljstvo temelji prije svega na ljudskoj odgovornosti, koja se nadopunjuje kršćanski oblikovanom savjesti. Iz svega slijedi da iz te dvije, naizgled razilazeće perspektive može i treba otvoriti prostor u pedagogiji, koja je djelatna znanost za diskurs (jedan od kršćanskim 
roditeljima najvažnijih), u kojem će se odgovorno roditeljstvo, osim s mnogobrojnim pedagoškim analizama, naputcima i savjetima, susresti sa svojom biti, a ta je da kršćanin nikad ne ljubi zato što ljubi, kršćanin uvijek ljubi in Christo, u Kristu.

\section{Literatura:}

AL. Amoris laetitia. U: Franjo, Amoris laetitia: Radost ljubavi: Posinodalna apostolska pobudnica biskupima, prezbiterima i đakonima, posvećenim osobama, kršćanskim supruzima i svim vjernicima laicima o ljubavi u obitelji. Zagreb: Kršćanska sadašnjost, 2016.

An. (2016). Ovo su najvažniji dijelovi sažetka Papine apostolske pobudnice o obitelji 'Amoris Laetitia'. U: Bitno.net. URL: https://www.bitno.net/vijesti/vatikan/ovo-jenajvazniji-dijelovi-sazetka-papine-apostolske-pobudnice-o-obitelji-amoris-laetitia/ (27. 05. 2017.)

Andrijanić, Goran (2016). Papa u razgovoru za novine Avvenire odgovorio kardinalima koji traže pojašnjenja od njega. U: Bitno.net. URL: https://www.bitno.net/vijesti/ papa-razgovoru-novine-avvenir-odgovorio-kardinalima-traze-pojasnjenja-njega/ (14. 05. 2017.)

Beck, Urlich (1986), Risikogesellschaft. Auf dem Weg in eine andere Moderne. Frankfurt, M.: Suhrkamp.

Bernstein, Gaia; Triger, Zvi (2011). Over-Parenting, UC Davis Law Review, 44, 4, 1221 1279.

Capelli, Giovanni (2009). Obitelj. U: Aldo Starić (ur.), Enciklopedijski teološki rječnik: Sveto pismo - Povijest - Duhovnost - Fundamentalna teologija - Dogmatika Moral — Ekumenizam — Religija. Zagreb: Kršćanska sadašnjost, 747-749.

Cline, Foster; Fay, Jim (1990). Parenting with love and logic: Teaching children responsibility. Colorado Spring s: Pinon Press.

Daly, Mary Catherine (ur.) (2008). Roditeljstvo u suvremenoj Europi: Pozitivan pristup. Zagreb: Ministarstvo obitelji, branitelja i međugeneracijske solidarnosti.

EG. Evangelii Gaudium. U: Franjo, Evangelii Gaudium: Radost Evanđelja: Apostolska pobudnica biskupima, prezbiterima i đakonima, posvećenim osobama i svim vjernicima laicima o naviještanju evanđelja u današnjem svijetu. Zagreb: Kršćanska sadašnjost, 2014.

Elkind, David (1995). School and Family in the Postmodern World. Phi Delta Kappan, 77, (1), URL: https://www.questia.com/read/1G1-17589557/school-and-family-in-thepostmodern-world (26. 06. 2017.).

Fuček, Ivan (1974). »Odgovorno roditeljstvo« — stvarnost ili utopija? Obnovljeni život, $29,3,245-263$.

Fuček, Ivan (1979). Ljubav i rađanje — odgovorno roditeljstvo. Bogoslovska smotra, 49, $1-2,80-95$.

Furedi, Frank (2008). Paranoid Parenting: Why ignoring the experts may be best for your child. London: Bloomsbury Academic.

GS. Gaudium et Spes. U: Paulus VI., Paulus episcopus servus servorum Dei una cum sacrosancti concilii patribus ad perpetuam rei memoriam constitutio pastoralis de ecclesia in mundo huius temporis (1) Gaudium et spes. URL: http://www.vatican.va/ archive/hist_councils/ii_vatican_council/documents/vat-ii_const_19651207_gaudiumet-spes_lt.html (13.01.2017.)

Haeffner, Gerd (2003). Filozofska antropologija. Zagreb: Naklada Breza. 
Honoré, Carl (2009). Pod pritiskom: Spašavanje naše djece od kulture hiperroditeljstva. Zagreb: Algoritam

HV. Humanae vitae. U: Pavao VI., Humanae vitae: Ljudski život: Enckilika o ispravnoj regulaciji poroda. Zagreb: Kršćanska sadašnjost, 2008.

Ivan Pavao II. (2003). Ljudska spolnost: istina i značenje: Odgojne smjernice u obitelji. Zagreb: Kršćanska sadašnjost.

Jeić, Minja; Smiljanić, Martina; Kuljašević, Katica (2013). Suradnja vrtića s roditeljima primjeri dobre prakse. Dijete, vrtić, obitelj, 19, 72, 4-6.

Juul, Jasper; Jensen, Helle (2012). Vom Gehorsam zur Verantwortung: Für eine neue Erziehungskultur. Weinheim: Beltz.

Jurčević Lozančić, Anka, Kunert, Ana (2015). Obrazovanje roditelja i roditeljska pedagoška kompetencija, teorijski i praktički izazovi. Metodički obzori: časopis za odgojnoobrazovnu teoriju i praksu, 10, 22, 39-48.

Koprek, Ivan (1997). Suvremeni čovjek i kriza vrednota. Bogoslovska smotra, 67, 2-3, 237-249.

Knorr Cetina, Karin; Bruegger, Urs (2002). Traders Engagement with Marcets: A Postsocial Realtionship. Theory, Culture \& Society, 19, 5/6, 161-185.

Ljubetić, Maja (2007). Biti kompetentan roditelj. Zagreb: Mali profesor.

Ljubetić, Maja (2011). Filozofija roditeljstva — obiteljsko ili društveno pitanje? Pedagogijska istraživanja, 8, 2, 283-293.

Ljubetić, Maja; Lepičnik-Vodopivec, Jurka (2012). Nosi li dobre roditelje roda?!: Odgovorno roditeljstvo za kompetentno dijete. Zagreb: Profil.

Maleš, Dubravka (2012). Obitelj i obiteljski odgoj u suvremenim uvjetima. Dijete, vrtić, obitelj, 18 (67), 13-15.

Matejević, Marina; Todorović, Jelisaveta (2012). Funkcionalnost porodičnih odnosa i kompetentno roditeljstvo. Niš: Filozofski fakultet.

Matulić, Tonči (2001). Aktualni problemi braka i obitelji: etičko-socijalni vid. U: Hrvatska obitelj na prekretnici, Baloban Stjepan (ur.), Glas Koncila, Zagreb, 169-219.

Matulić, Tonči (2009). Metamorfoze kulture: Teološko prepoznavanje znakova vremena u ozračju znanstveno-tehničke civilizacije. Zagreb: Glas Koncila.

MV. Misericordiae vultus. U: Franjo, Misericordiae vultus: Lice milosrđa: Bula najave izvanrednoga jubileja milosrđa. Zagreb: Kršćanska sadašnjost, 2015.

Odgojne smjernice o ljudskoj ljubavi. U: Kongregacija za katolički odgoj i izobrazbu, Odgojne smjernice o ljudskoj ljubavi: Obrisi spolnoga odgoja. Zagreb: Kršćanska sadašnjost, 1996.

Pećnik, Ninoslava (2008). Suvremeni pogledi na dijete, roditeljstvo i socijalizaciju. Dijete $i$ društvo, 10, 1/2, 99-115.

Petani, Rozana; Babačić, Ante (2010). Motivacija za roditeljstvo kod studenata Sveučilišta u Zadru. Acta Ladertina, 7, 1, 79-97.

Pranjić, Marko (2010). Kontinuitet i diskontinuitet starogrčkih odgojnih sadržaja u hrvatskoj pedagoškoj praksi. Kroatologija, 1, 1, 228-253.

Raguž, Ivica (2017). O ljubavi. U: Svjetlo riječi, URL: https://www.svjetlorijeci.ba/ kolumne/o-ljubavi ( 25. 04. 2017.)

Ramaekers, Stefan; Suissa, Judith (2012). The claims of parenting: Reasons, responsibility and society. Dordrecht: Springer.

Schönborn, Christoph (2016). Schönborn: Ključne riječi dokumenta 'Amoris Laetitia'. U: Vatikanski Radio. URL: http:/hr.radiovaticana.va/news/2016/04/08/ sch\%C3\%B6nborn_klju\%C4\%8Dne_rije\%C4\%8Di_dokumenta_amoris_laetitia /1221387 (18. 03. 2017.) 
Smith, Richard (2010). Total Parenting. Educational Theory, 60, 3, 357-369.

Spasojević, Pero (2011). Porodična pedagogija i odgovorno roditeljstvo. Udžbenik za studente pedagoških fakulteta i priručnik za roditelje, vaspitače i nastavnike. Banja Luka: Nova škola.

Štengl, Ivan (2015). Sistemski pristup u dušobrižništvu braka i obitelji u krizi. Bogoslovska smotra, 85, 3, 701-726.

Sunko, Esmeralda (2008). Utjecaj provedbe programa za roditelje na njihove stavove o odgoju. Odgojne znanosti, 10, 2, 383-401.

Tomašević, Luka; Begić Ana (2010). Enciklika Caritas in veritate — Ljubav u istini. Služba Božja, 50, 2, 161-183.

Vukasović, Ante (2009). Prijeka potreba odgoja za obiteljski i društveni život. Obnovljeni život, 64, 1, 69-85.

Wilk, Liselotte (2003). Familienform als Determinante kindlicher Entwicklung und kindlichen Glücks? U: Rosa Heim i Christian Posch (ur.), Familienpädagogik: Familiäre Beziehungen mit Kindern professionell gestalten (str. 13-34). Innsbruck — Wien München - Bozen: Studien Verlag.

Zbodulja, Sanja (2014). Utjecaj roditeljskih stilova odgoja na ponašanje djeteta (Diplomski rad). Sveučilišni diplomski studij sestrinstva, Medicinski fakultet, Sveučilište u Zagrebu, Zagreb.

Responsible Parenthood in the Post-Synodal Apostolic Exhortation Amoris Laetitia - Theological-Pedagogical Perspectives

Martina Sr. Ana Begić*, Katarina Dadić**

\section{Summary}

The topic of responsible parenthood has not been sufficiently researched in Croatian theological literature, unlike pedagogical literature wherein it has been given more attention. Since the term žresponsible parenthood' is not interpreted in the same way by these two sciences, the authors recognized the need to highlight more clearly the theological-pedagogical perspectives by examining Pope Francis' Post-Synodal Apostolic Exhortation Amoris Laetitia - The Joy of Love. The theological perspective stresses that responsible parenthood is based on human responsibility complemented by a Christian conscience and offers it as such to pedagogy as a possibility. The first four sections of the paper cover an analysis of the document Amoris Laetitia while the fifth section presents responsible parenthood from the perspective of contemporary pedagogical science.

Key words: family, child, responsible parenthood, upbringing, Amoris Laetitia

* Martina s. Ana Begić, Ph.D., Catholic Faculty of Theology, University of Zagreb. Address: Vlaška 38, 10000 Zagreb, Croatia. E-mail: ana.begic@gmail.com

** Katarina Dadić, Ph.D., Faculty of Philosophy, University of Zagreb. Address: Ivana Lučića 3, 10 000 Zagreb, Croatia. E-mail: katdadic@gmail.com 